\title{
Age and petrogenesis of the Sarmiento ophiolite complex of southern Chile
}

\author{
C. R. STERN ${ }^{1}$, S. B. MUKASA ${ }^{2}$, and R. FUENZALIDA P. $^{3}$ \\ ${ }^{1}$ Department of Geological Sciences, University of Colorado, Boulder, CO 80309-0250, USA; \\ ${ }^{2}$ Department of Geological Sciences, University of Michigan, Ann Arbor, MI 48109-1063, USA; \\ ${ }^{3}$ Empresa Nacional del Petroleo, Casilla 11135, Santiago, Chile
}

(Received September 1992; Revision Accepted November 1992)

\begin{abstract}
Zircon fractions separated from fine-grained plagiogranites, interpreted to be cogenetic with the mafic rocks of the Sarmiento ophiolite complex in southern Chile, yield slightly to grossly discordant age patterns for which the lower concordia intercept U-Pb ages of 140.7 $\pm 0.7 \mathrm{Ma}$ (Lolos Fjord) and 137.1 $\pm 0.6 \mathrm{Ma}$ (Encuentro Fjord) are well constrained. These dates are interpreted as formation ages for the northem portion of the igneous floor of the Rocas Verdes basin, and they are younger than the age of $150 \mathrm{Ma}$ determined for a more southern portion of the floor of this basin on South Georgia Island. Coarse-grained trondhjemites within the gabbro units of the Sarmiento complex yield a lower concordia intercept $\mathrm{U}-\mathrm{Pb}$ age of $147 \pm 10 \mathrm{Ma}$ and a poorly defined upper intercept reflecting an inherited zircon component, possibly of Proterozoic age. These rocks are interpreted as remobilized fragments of country rocks entrapped within the essentially mantle-derived rocks of the ophiolite complex.

Resumen-Fracciones de zircón separadas de plagiogranitos de grano fino, que han sido interpretados como cogenéticos con las rocas máficos del Complejo Ofiolítico Sarmiento en el sur de Chile, arrojan patrones de edades levemente a fuertemente discordantes para las cuales el valores de intersección de la concordia inferior de edades $\mathrm{U}-\mathrm{Pb}$ están bien definidos y corresponden a $140.7 \pm \quad 0.7 \mathrm{Ma}$ (Fjordo Lolos) y $137.1 \pm 0.6 \mathrm{Ma}$ (Fjordo Encuentro). Estas edades se interpretan como edades de formacón de la zona norte del fondo ígneo de la cuenca de Rocas Verdes y son más jóvenes que la edad de 150 Ma determinada para la zona sur del fondo de esta cuenca en la Isla South Georgia. Trondjomitas de grano grueso dentro de la unidad de gabro del Complejo Sarmiento entregan una intersección de la conordia inferior de edades U-Pb de $147 \pm 10 \mathrm{Ma}$ y un valor de intersección superior debilmente definido, posiblemente reflejando una componente de zircón heredada de edad Proterizoica. Estas rocas se interpretan como fragmentos removilizados de la roca de caja, atrapados en rocas ofiolíticas derivadas esencialemente del manto.
\end{abstract}

\section{INTRODUCTION}

THE BELT of dominantly mafic Rocas Verdes igneous complexes in the southernmost Andes (Fig. 1A) represents the uplifted, but autochthonous, igneous floor of an Early Cretaceous back-arc basin (Dalziel et al., 1974) or Gulf of California type ensialic basin (Alabaster and Storey, 1990). The ages of the Rocas Verdes mafic complexes of southern Chile are constrained by stratigraphic data (Bruhn $e t$ al., 1979; Fuenzalida and Covacevich, 1988) but have not previously been determined isotopically, in part because of extensive spilitization related to hydrothermal metamorphism, and in part because rocks with minerals suitable for dating are scarce. Zircon U-Pb age determinations are presented here for two petrologically distinct suites of silicic rocks which are important components of the Sarmiento complex, the northernmost of the Rocas Verdes ophiolite complexes. These silicic rocks include plagiogranites. which have previously been interpreted as cogenetic with the mafic rocks of the Sarmiento complex, and trondhjemites, which have been interpreted as remnants of older continental crust engulfed within this ophiolite complex (Stern, 1979; Saunders et al., 1979; De Wit and Stern, 1981).

\section{SAMPLE DESCRIPTION AND GEOCHEMISTRY}

The Sarmiento complex consists of gabbros and of mafic dikes and pillow lavas interpreted to represent the upper sections of an ophiolitic sequence formed along an oceanic-type spreading center which rifted the South American crust during the Late Jurassic and Early Cretaceous to produce the Rocas Verdes basin (Dalziel et al., 1974, Bruhn et al., 1978). Geochemical studies of mafic rocks from the Sarmiento and other Rocas Verdes complexes indicate close similarities with ocean ridge basalts (Stern, 1979. 1980, 1991; Alabaster and Storey, 1990).

The samples of silicic plagiogranites and trondhjemites analyzed in this study were collected from exposures along the northern shores of Lolos and Encuentro Fjords, which cut perpendicularly across the regional north-south strike of dikes within the Sarmiento complex (Fig. 1B). At these localities the lower $500-800 \mathrm{~m}$ of outcrop is formed by the plutonic unit of the ophiolite, including mafic gabbros and diorites as well as leucocratic plagiogranites and trondhjemites described below (Fig. 2). The upper portions of these sections consist of the sheeted dike complex of the ophiolite. which grades upward into pillow lavas and breccias.

Address all correspondence and reprint requests to Dr. Charles R. Stern: telephone [1] (303) 492-8141; fax [1] (303) 492-2606 


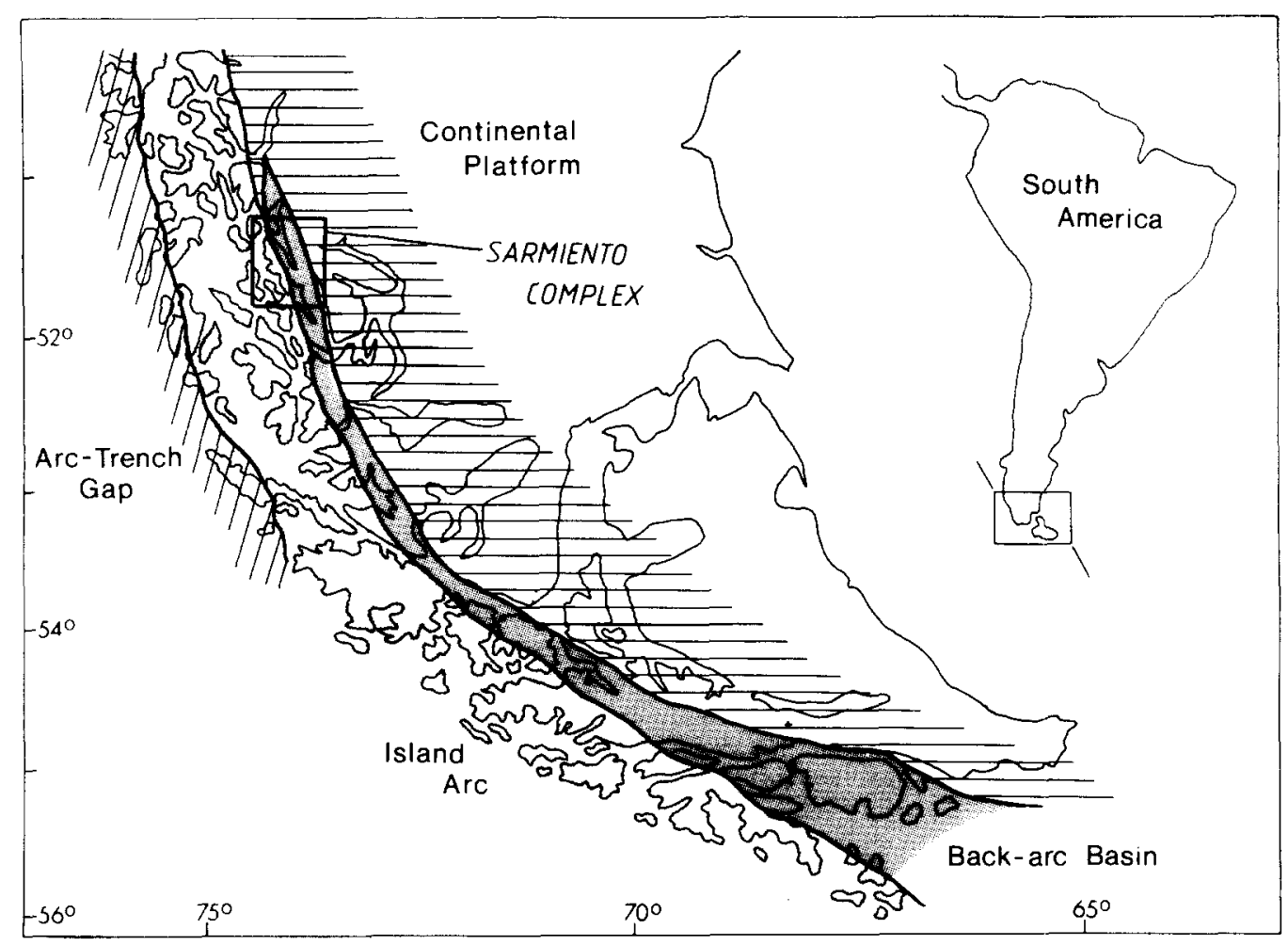

Fig. 1A. Map showing the location of the Sarmiento complex within the context of the major lithotectonic units of the southernmost Andes during the late Mesozoic (Dalziel et al., 1974).

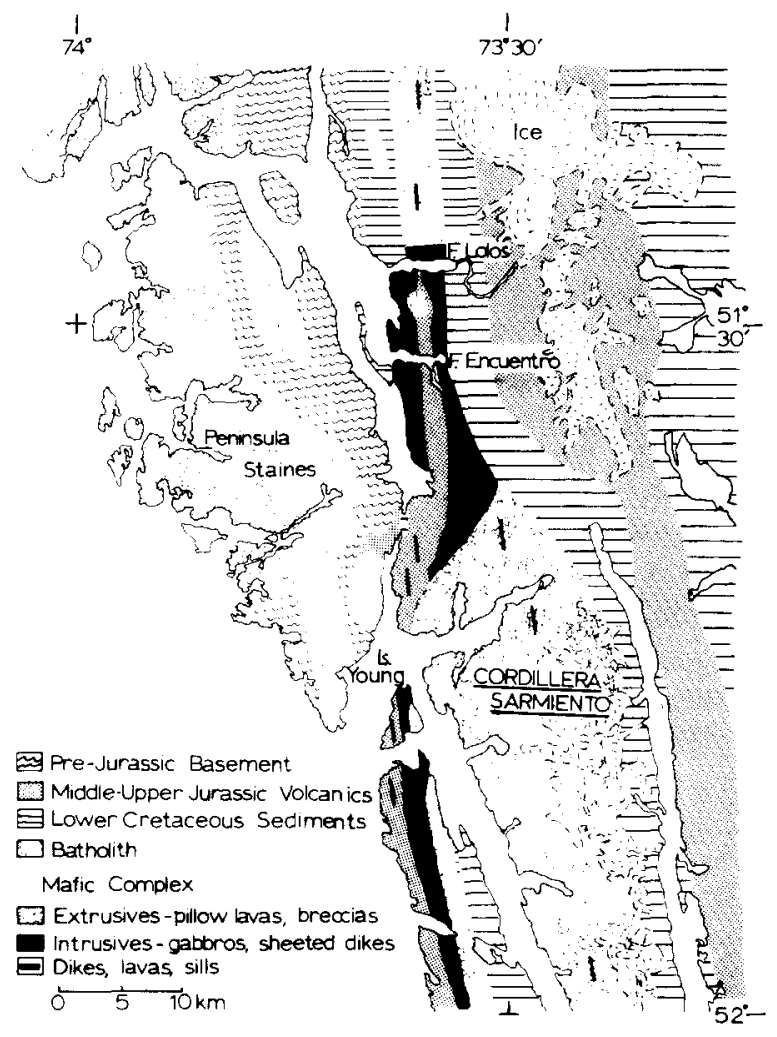

Fig. 1B. Map showing the distribution of the main rock types of the Sarmiento ophiolite complex (Stern, 1979). Samples for dating came from the northern shores of Lolos and Encuentro Fjords.
Plagiogranites in the Sarmiento ophiolite occur as fine-grained leucocratic rocks either in a plutonic body intruding the sheeted dike complex, or as dikes within the sheeted dike complex and the overlying pillow lavas (Fig. 2: Stern, 1979; De Wit and Stern, 1981). The plagiogranite plutonic body. which marks the contact between the lower plutonic unit of the ophiolite and the sheeted dike complex, intruded the sheeted dike complex by magmatic stoping. It is approximately 50-100 to $\mathrm{m}$ thick and grades downward across a diffuse boundary into trondhjemite, diorite, and gabbro. The pluton itself is cut by later mafic dikes, indicating that the plagiogranites are contemporaneous with the mafic magmatic activity which produced the Sarmiento ophiolite complex.

Hydrothermal "ocean-floor" metamorphism at greenschist facies conditions $\left(200-500^{\circ} \mathrm{C}\right)$ has modified the original mineralogy and geochemistry of the plagiogranites (Stern $e t$ al., 1976; Stern and Elthon. 1979; Elthon $e t$ al., 1984). The concentrations of mobile major and trace elements, particularly alkali elements such as $\mathrm{K}$ and $\mathrm{Rb}$, have been significantly modified, in both mafic rocks and the plagiogranites, by this metamorphism. However, the concentrations of immobile trace elements, such as rareearth elements (REE) and high-field-strength elements (HFSE: Nb. Zr, Ti, Y) do not appear to have been affected (Stern and Elthon, 1979). The immobile elements exhibit coherent trends through the basalt-ferrobasalt-andesiteplagiogranite sequence of the complex (Fig. 3; Stern, 1979; Saunders et al., 1979). These coherent chemical trends among the immobile trace elements suggest that the plagiogranites are cogenetic with the associated mafic rocks 


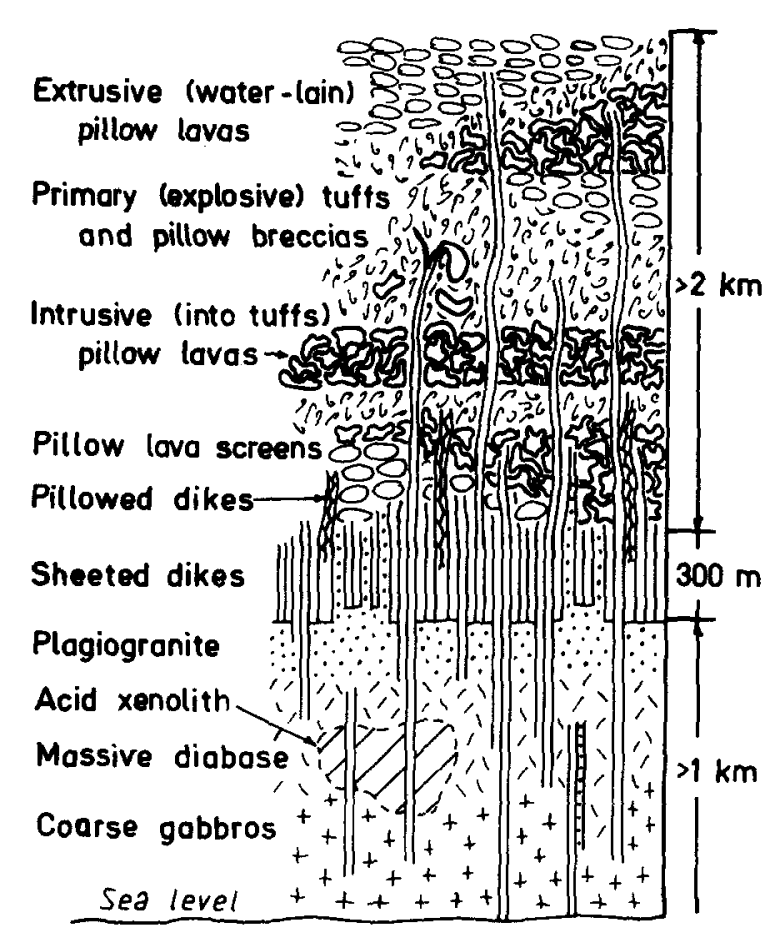

Fig. 2. Pseudostratigraphic cross-section of the Sarmiento ophiolite complex showing the mutually intrusive inter-relation of mafic dikes and plagiogranites, which imply contemporaneity of these two units, and the typical location of trondhjemites (labled as "acid xenolith") within the plutonic unit of the ophiolite (Stern, 1979). of the complex. They are interpreted to have formed from mafic magmas by closed-system igneous fractionation involving the crystallization and separation of the large proportion of Fe-Ti oxides found concentrated in ferrogabbros within the gabbro unit of the Sarmiento complex (Stern, 1979; Saunders et al., 1979).

Table 1 presents seven new chemical analyses of plagiogranites which formed a portion of the large sample $(>50 \mathrm{~kg}$ ) collected from Encuentro Fjord for zircon dating. These samples exhibit relatively high $\mathrm{Zr}$ (Fig. 3), $\mathrm{Nb}$, and $Y$ contents, compared with the associated mafic rocks of the Sarmiento complex, which is consistent with the plagiogranites being the end-product of extensive crystalliquid fractionation of these mafic rocks (Stern, 1979). They also have the anomalously low $\mathrm{K}$ and $\mathrm{Rb}$ contents previously noted from other Sarmiento plagiogranites and explained as a result of removal during hydrothermal metamorphism (Stern and Elthon, 1979; Saunders et al.. 1979).

Trondhjemites of the Sarmiento complex are coarsegrained leucocratic rocks which occur between the plagiogranites and the underlying mafic gabbros (Fig. 2). The trondhjemites typically crop out over a vertical distance of 100 to $200 \mathrm{~m}$, but both their upper and lower boundaries are diffuse and difficult to identify in the field. They are cut by numerous mafic dikes, as is the plagiogranite. In thin section, trondhjemites are quite distinct from plagiogranites, being coarser grained and containing

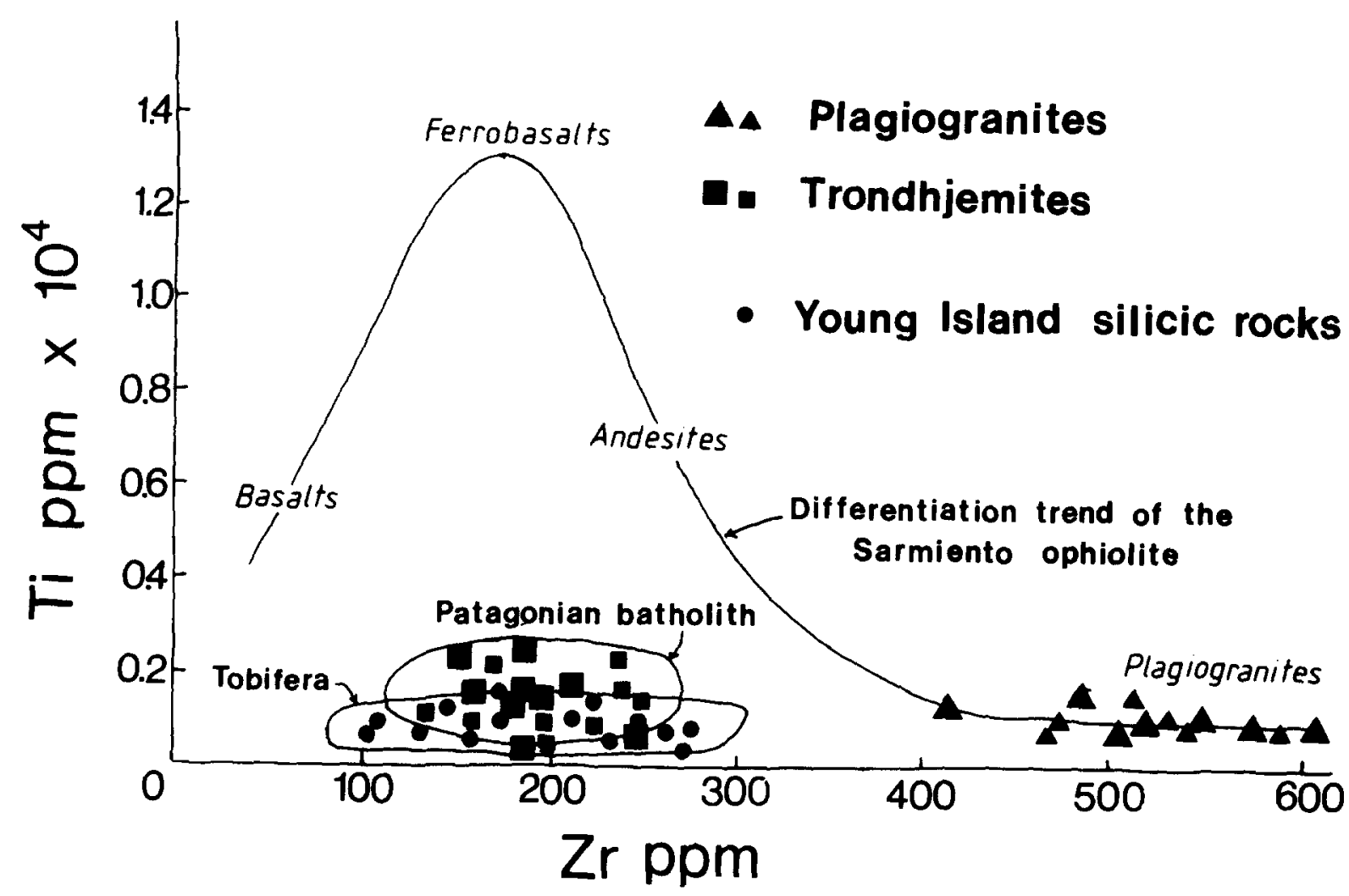

Fig. 3. $\mathrm{TiO}_{2}$ versus $\mathrm{Zr}$ content for plagiogranites (triangles) and trondhjemites (squares) from the Sarmiento complex. Larger symbols are new data (Table 1) and smaller symbols are previously published data (Stern, 1979; Stern and Elthon, 1979; Saunders et al., 1979). Trend for basalt-ferrobasalts-andesites-plagiogranites from the Sarmiento complex is taken from Stem (1979). Fields for silicic Tobifera volcanic rocks and plutons of the Patagonian batholith, as well as analyses of silicic rocks engulfed in mafic igneous rocks on Young Island (circles) to the south of Lolos and Encuentro Fjords (Fig. 1B), are taken from De Wit and Stern (1981). 


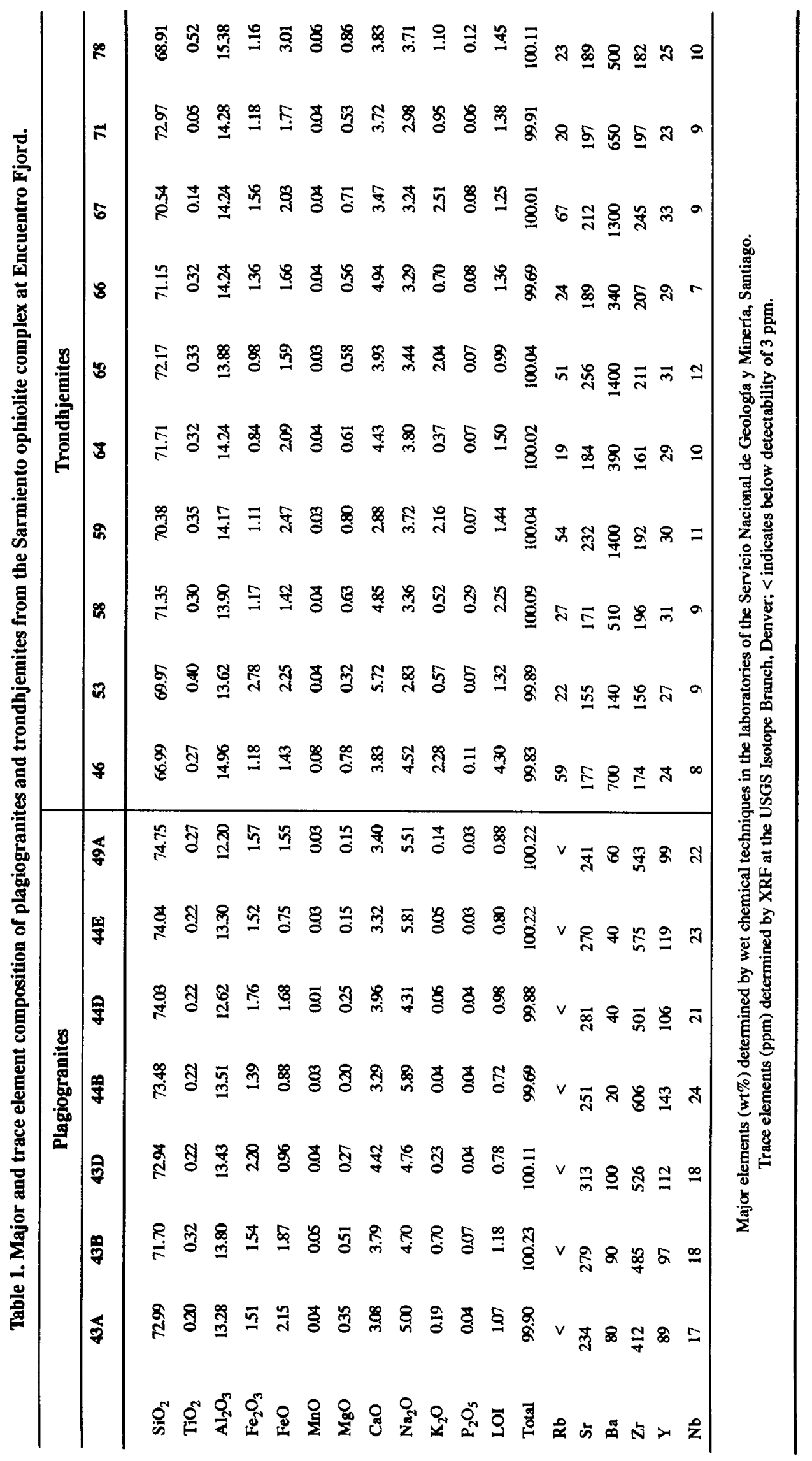


a somewhat higher proportion of mafic minerals such as biotite, chlorite, and epidote, as well as alkali feldspar. Also, trondhjemites characteristically contain quartz orbicules and both myrmekitic intergrowths between quartz and plagioclase and graphic intergrowths of quartz and alkali feldspars.

Petrologically, these trondhjemites resemble remobilized xenoliths of older silicic country rocks, either Tobifera Formation silicic volcanic or granites of the Patagonian batholith, found cut by numerous mafic dikes and intruded by gabbros along the margins of the Sarmiento complex, such as on Young Island (Fig. 1B; De Wit and Stern, 1981). The trondhjemites exposed in Lolos and Encuentro Fjords have also been interpreted as remnants of remobilized country rocks engulfed in the mafic rocks of the ophiolite. This interpretation is supported by geochemical data which indicate that compared to the plagiogranites, these trondhjemites have lower HFSE contents (Fig. 3) and higher $\mathrm{La} / \mathrm{Yb}$ ratios and more closely resemble both the granitic plutons of the Patagonian batholith and silicic volcanic rocks of the Jurassic Tobifera Formation, which are suggested as their possible precursor lithologies (De Wit and Stern, 1981).

Tablel presents analyses of eleven samples of trondhjemites which formed a portion of the large sample $(>50 \mathrm{~kg}$ ) collected in Encuentro Fjord for zircon U-Pb dating. These samples have lower and more variable $\mathrm{SiO}_{2}$, higher $\mathrm{MgO}$ and $\mathrm{K}_{2} \mathrm{O}$, and significantly lower $\mathrm{Zr}$ (Fig. 3) and $\mathrm{Y}$ contents than plagiogranites. Also, their $\mathrm{Ba}$ contents are higher than plagiogranites, and some samples. which also have high $\mathrm{K}_{2} 0$, have extremely high $\mathrm{Ba}$. Chemically similar samples have been referred to previously as the granophyre phase of the trondhjemites (Saunders et al., 1979), and they may have formed by concentration of partial melts derived from the precursor trondhjemite lithology. These samples contain abundant graphic intergrowths of quartz and alkali feldspar.

\section{RESULTS AND DISCUSSION}

The analytical techniques, data, and calculated ages for samples of plagiogranites and trondhjemites from both Lolos and Encuentro Fjords are presented in Table 2. Figure 4 presents these data on concordia diagrams.

Zircons separated from plagiogranites collected in Lolos and Encuentro Fjords are slightly to grossly discordant, yielding lower intercept ages of $140.7 \pm 0.7$ and $137.1 \pm 0.6 \mathrm{Ma}$, respectively (Fig. 4A). We interpret these as formation ages for these outcrops of the Sarmiento complex. Although the plagiogranites are cut by some later mafic dikes, these ages are considered to be close to the minimum age for the igneous activity that formed this portion of the floor of the Rocas Verdes basin. Upper intercept ages for these rocks range from Proterozoic to Archean but have large errors that reduce their chronological significance.

Fuenzalida and Covacevich (1988) established a minimum stratigraphic age of late Tithonian, or $145 \pm 5 \mathrm{Ma}$. for mafic lavas of the Sarmiento complex on Peninsula
Taraba south of Lolos and Encuentro Fjords. The small differences between this age and the isotopic ages for the two plagiogranite bodies in Lolos and Encuentro Fjords may reflect the actual time that elapsed while different portions of the Sarmiento complex formed by extensionrelated igneous activity.

Trondhjemites from Lolos Fjord yield a lower intercept age of $147 \pm 10 \mathrm{Ma}$ (Fig. 4B). The points for the Lolos Fjord trondhjemites are not strictly linear, which may be explained by either inherited zircons in each fraction having slightly different thermal histories or by different samples having different ages. These data are consistent with the suggestion that the trondhjemites represent remobilized fragments of country rock engulfed within the essentially mantle-derived ophiolite complex. The upper intercept for these samples is $2935 \mathrm{Ma}$, but the error for this age is excessively large. A younger Proterozoic age for the inherited zircons is supported by other $\mathrm{U}-\mathrm{Pb}$ studies of igneous rocks from the Austral Andes (Herve et al., 1991; Mukasa and Dalziel, 1992).

Field and petrochemical data suggest that the Rocas Verdes back-arc basin widened and its mafic igneous floor became more oceanic in character south of the Sarmiento complex (Stern, 1979, 1980, 1991; De Wit and Stern, 1981). An age of $150 \pm 1 \mathrm{Ma}$ has been obtained for the igneous floor of a more southern portion of the Rocas Verdes basin now exposed on South Georgia Island (Mukasa and Dalziel, 1992). This older age suggests that the basin may have opened by unzipping from south to north, with the more southern portions beginning to form earlier, and developing more extensively in an oceanic setting, than the northern portion of the basin in the vicinity of the Sarmiento complex. Alternatively, the greater width and more oceanic character of the southern part of the Rocas Verdes basin may reflect regional differences in spreading rate rather than the duration of extension-related igneous activity associated with the basin's development. In this case, each of the different ages reported here and by Mukasa and Dalziel (1992) may represent only specific events within a longer time period during which extensionrelated igneous activity produced the different parts of the mafic floor of the Rocas Verdes basin.

Alabaster and Storey (1990) reported chemical data suggesting that the Rocas Verdes basin did not develop in a back-arc supra-subduction-zone setting but rather in an oblique-slip margin akin to that of the Gulf of California. However, Halpern (1973) and Bruce et al. (1991) have dated a number of I-type plutons of the southern Patagonian batholith, south and west of the Rocas Verdes ophiolite belt, in the age range 151 to $138 \mathrm{Ma}$, contemporaneous with the mafic igneous activity that formed these ophiolites. The Patagonian batholith has been interpreted as the roots of a convergent plate boundary magmatic arc (Dalziel et al., 1974; Stern and Stroup, 1982; Bruce et al., 1991). The presence in this batholith of plutons of similar age to the mafic floor of the Rocas Verdes basin is consistent with the original suggestion of Dalziel et al. (1974) that this was a back-arc basin, the development of which rifted the continental crust north and east of a contemporaneous magmatic arc active along the continental margin. 


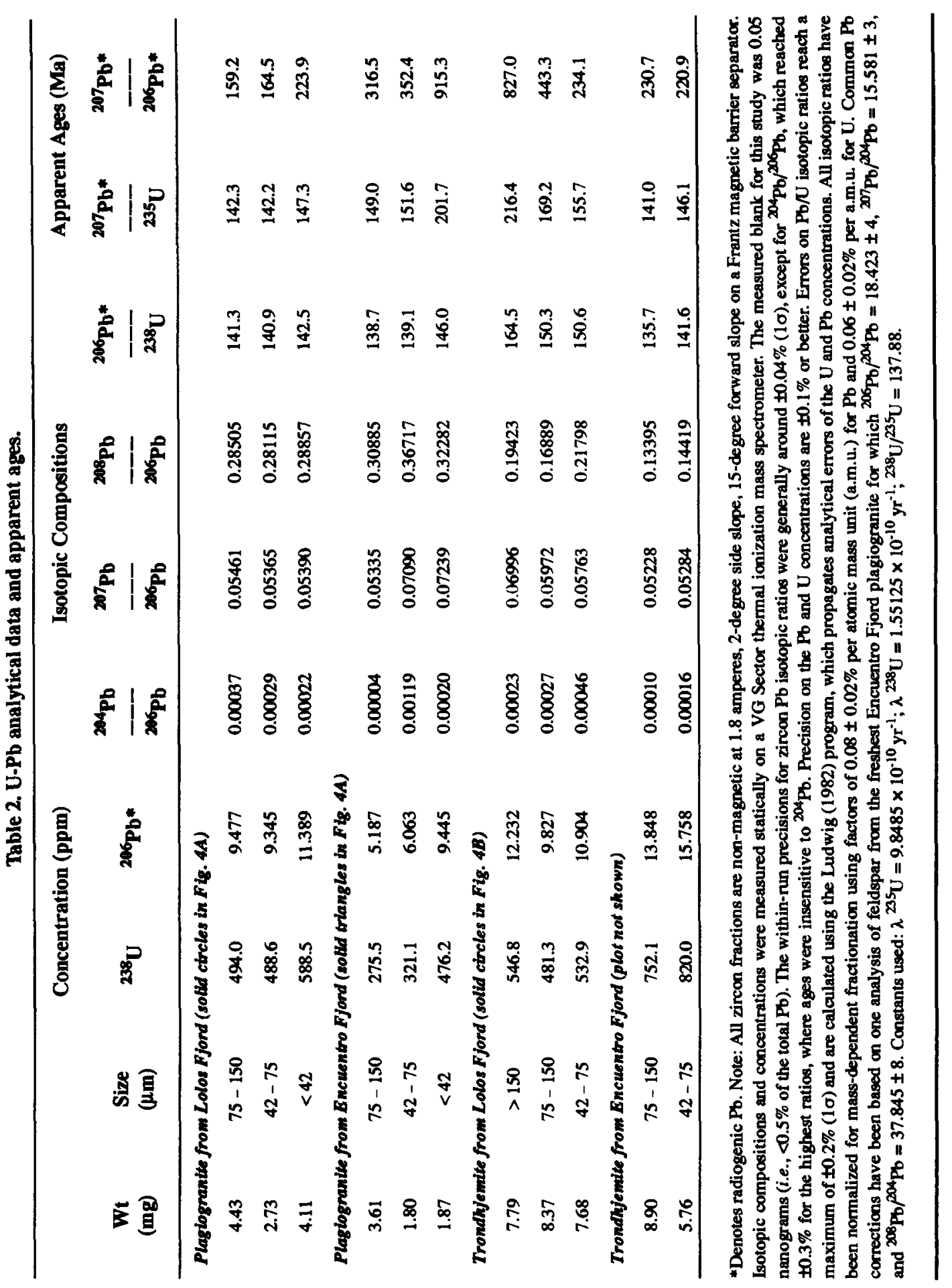



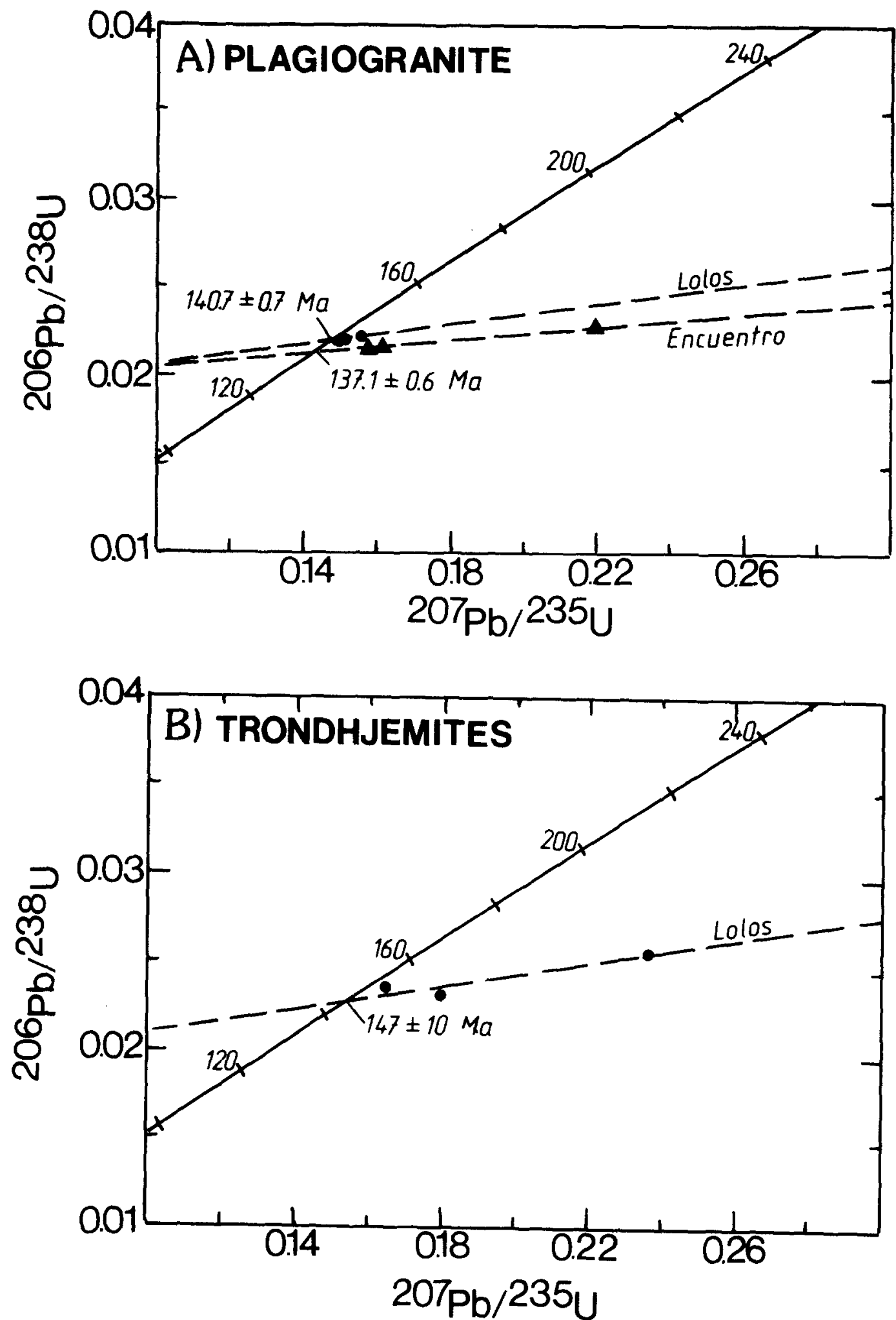

Fig. 4. U-Po concordia diagrams showing the lower intercepts for samples of (A) plagiogranites from Lolos (circles) and Encuentro (triangles) Fjords, and (B) trondhjemites from Lolos Fjord. Error ellipses for each data point are smaller than the symbols used. The concordia upper intercepts are not included on the diagrams because they have large errors and no particular chronological significance other than to broadly constrain the age of inherited zircon components as Precambrian. 
Aknowledgments-We thank the Empressa Nacional del Petroleo, Chile, for logistic support. The isotopic work was supported in part by National Science Foundation grant DPP-8643441.

\section{REFERENCES}

Alabaster, T., and Storey, B. C., 1990. Modified Gulf of California model for South Georgia, north Scotia Ridge, and implications for the Rocas Verdes back-arc basin, southern Andes. Geology 18, 497-500.

Bruce, R. M., Nelson, E. P., Weaver, S. G., and Lux, D. R., 1991. Temporal and spatial variations in the southem Patagonian batholith: Constraints on magmatic arc development. In: Andean Magmatism and Its Tectonic Setting (edited by R. S. Harmon and C. W. Rapela). Geological Society of America, Special Paper 265,1-13.

Bruhn, R. L., Stern, C.R., and De Wit, M. J., 1978. Field and geochemical data bearing on the development of a Mesozoic volcano-tectonic rift zone and back-arc basin in southernmost South America. Earth and Planetary Science Letters 41, 32-46.

Dalziel, I. W. D., De Wit, M., and Palmer, K. F., (1974. Fossil marginal basin in the southem Andes. Nature 250, 291-294.

De Wit, M. J., and Stern, C.R., 1981. Variations in the degree of crustal extension during the formation of a back-arc basin. Tectonophysics 72, $229-260$.

Elthon D., Lawrence, J. R., Hanson, R. E., and Stern, C. R., 1984. Modelling of oxygen isotope data from the Sarmiento ophiolite complex, Chile. In: Ophiolites and Oceanic Lithosphere (edited by I. Gass, S. Lippard, and A. Shelton), pp. 185-197. Blackwell Scientific Publications, London, England, UK.

Fuenzalida, R., and Covacevich, V., 1988. Volcanismo y biostratigrafia del Jurásico y Cretácico Inferior en la Cordillera Patagónica, Región de Magallanes, Chile. Actas, V Congreso Geologico Chileno, Santiago 3, H159-H183.

Halpern, M., 1973. Regional geochronology of Chile south of $50^{-\mathrm{S}}$ latitude. Bulletin of the Geological Society of America 84, 2407-2422.
Herve, F., Loske, W. P., Miller, H., and Pankhurst, R. J., 1991. Chronology of provenance, deposition and metamorphism in the southem limb of the Scotia Arc. In: Geologic Evolution of Antarctica (edited by M. R. A. Thomson, J. A. Crame, and J. W. Thomson), pp. 429435. Cambridge University Press, Cambridge, England, UK.

Mukasa, S. B., and Dalziel, I. W. D., 1992. Southem Andes and South Georgia Island, north Scotia Ridge: Zircon U-Pb and muscovite ${ }^{40} \mathrm{Ar} /$ ${ }^{39} \mathrm{Ar}$ age constraints on the kinematic evolution of southwestern Gondwanaland. Tectonics, in press.

Saunders, A. D., Tarney, J., Stern, C. R., and Dalziel, I. W. D., 1979. Geochemistry of Mesozoic marginal basin foor igneous rocks from southern Chile. Bulletin of the Geological Society of America 90 , 237-258.

Stern, C. R., 1979. Open and closed system igneous fractionation within two Chilean ophiolites and the tectonic implications. Contributions to Mineralogy and Petrology 68, 243-258.

Stern, C. R., 1980. Geochemistry of Chilean ophiolites: Evidence of the compositional evolution of the mantle source of back-arc basin basalts. Journal of Geophysical Research 85, 955-966.

Stern, C. R., 1991. Isotopic composition of Late Jurassic and Early Cretaceous mafic igneous rocks from the southernmost Andes: Implications for sub-Andean mantle. Revista Geologica de Chile 18, 15-23.

Stern, C. R., and Elthon, D., 1979. Vertical variations in the effects of hydrothermal metamorphism in Chilean ophiolites: Their implications for ocean floor metamorphism. Tectonophysics 55, 179-213.

Stern, C. R., and Stroup, J. B., 1982. The petrochemistry of the Patagonian batholith, Ultima Esperanza, Chile. In: Antarctic Geoscience (edited by C. Craddock), pp. 135-142. University of Wisconsin Press, Madison, WI, USA.

Stern, C. R., De Wit, M. J., and Lawrence, J. R., 1976. Igneous and metamorphic processes associated with the formation of Chilean ophiolites and their implications for ocean floor metamorphism, seismic layering and magnetism. Journal of Geophysical Research 81, 43704380 